\title{
OTHER COMPREHENSIVE INCOME AND EARNINGS MANAGEMENT AN EMPIRICAL ANALYSIS BASED ON MODIFIED JONES MODEL
}

\author{
Prof. Feng Yin \\ School of Economics, Shanghai University, P.R.China \\ Qiangling Zheng \\ School of Economics, Shanghai University, P.R.China
}

\begin{abstract}
Based on the revised Jones model, this paper studies the relationship between earnings management and other comprehensive income using the sample date of Chinese A-share listed companies in 2008-2015. It is found that the presentation of other comprehensive income can reduce the degree of earnings management of listed companies under the same factors. If other factors keep still, the listed companies with surplus management motives have more other comprehensive income that transferred to the current profit and loss. This study provides Experience support for the agency, which implement mandatory and transparent presentation and disclosure of other comprehensive income.
\end{abstract}

Keywords: Other comprehensive income; Earnings management; Revised Jones model

JEL code: M10

\section{Introduction}

There are three main ways to convert the other comprehensive income into the current profit and loss: the first is the reclassification of financial assets, the second is the long-term equity investment using the equity method, the third is the change of the fair value of the available-forsale financial assets, Of the recognition, the other comprehensive income into the current profits and losses. Listed companies are generally different degree of earnings management behavior, since 2007, the implementation of the new accounting standards of the "investment income" and "fair value gains and losses" into the "operating profit", listed companies are more inclined to use other comprehensive income Into the current profit and loss earnings management to achieve the goal of profit. According to the accounting explanation (2009) issued by the Ministry of Finance, "other comprehensive income" and "comprehensive income" are listed in the income statement. Further the accounting standards promulgated by the Ministry of Finance (2014), the inclusion of a series of other comprehensive income elements more clearly and transparently incorporated into the accounting standards. Based on the revised Jones model, this paper uses the method of multiple regression analysis to study the relationship between other comprehensive income and earnings management in all the A - share listed companies in Shanghai and Shenzhen from 2008 to 2015.The empirical results of this paper provide further support for other comprehensive benefits in the statements. The contribution of this paper is not only from the impact of other 
comprehensive returns on the degree of earnings management, but also from the existence of earnings management motivation of other companies to other comprehensive income into the current profit and loss perspective on the impact of the use of large sample empirical data comparison Analyze the relationship between other comprehensive earnings and earnings management for 2009-2015.

\section{Literature review}

Dhaliwal (1999) used US companies in 1994 and 1995 for two years to study data that compared to traditional net profits, other comprehensive income did not provide more information on the company's stock return on investment, nor did it provide a forecast for future cash flow accurate information.

Biddle and Choi (2002) studied the relationship between other comprehensive income items and managerial and stock yields, and found that other comprehensive returns were higher than traditional net profit, but other comprehensive income was higher The interpretation of the performance of the layer is weaker than the traditional net profit.

Lee (2006) to insurance companies as the object of study, the results found that the greater the motivation for earnings management of the insurance companies tend to choose to change in the shareholders of the table on the other comprehensive income statement; insurance companies in the earnings management is inclined to choose to sell the financial assets.

Kanagaretnam et al. (2009) found that other comprehensive income and comprehensive benefits were bad and traditional net profit in predicting future earnings persistence through empirical studies. The sample is the other comprehensive income experience data for Canadian companies listed in the United States from 1998 to 2003.

Li Hui (2010) based on 2005 - 2008 Shenzhen SME version of listed companies data, research for small and medium enterprises, earnings management and information disclosure between the relationship. The results show that there is a significant negative correlation between the earnings management of SME listed companies and the quality of information disclosure in other factors.

Wang Xin (2013) as a sample of the non-financial industry companies listed on China's Shanghai and Shenzhen A-listed companies from 2009 to 2011 examined the correlation between the value of other comprehensive income and total consolidated income. As a result the fair value of the financial assets for sale is significantly related to the stock price. The disclosure and presentation of the consolidated income can increase the usefulness of the financial report.

Ouyang Aiping \& Zheng Chao (2014) Based on the data of China A-share listed companies from 2009 to 2001 the impact of other comprehensive income information on creditors is studied. The results show that the other comprehensive income has the usefulness of credit decision-making; the comprehensive utilization of credit decision-making usefulness is higher than the net profit of credit decision-making usefulness.

Yang Kezhi (2016) Based on the 2007 and 2014 A-share listed companies in Shanghai and Shenzhen, LOGISTIC regression method was used to study the relationship between other 
comprehensive income and earnings management. The result was that the listed companies could control and adjust Other comprehensive income into the current profit and loss of time and amount in order to achieve the goal of earnings management; other comprehensive income presentation transparency can be to a certain extent, this other comprehensive income as earnings management tools to implement earnings management behavior.

In this paper the LOGISTIC regression method is used to study the relationship between other comprehensive income and earnings management. The result is that the listed companies can control and adjust the relationship between the listed companies and the listed companies. Other comprehensive income into the current profit and loss of the time and amount in order to achieve the goal of earnings management; other comprehensive income presentation transparency can be to a certain extent this other comprehensive income as earnings management tools to implement earnings management behavior.

At home and abroad on other comprehensive income research focused on its asset pricing function that is more of its value relevance. There are few studies on the corporate governance functions of other integrated returns as some countries such as US accounting standards are the way in which listed companies can independently choose other comprehensive returns. The domestic scholars' research on the corporate governance function of other comprehensive income is the effect of the other comprehensive income on the degree of earnings management and there is no research on the influence of the earnings management motive of the listed company on the other comprehensive income into the current profit and loss.

\section{Research assumptions and model construction}

\subsection{Hypothesis}

In June 2009 the Ministry of Finance issued the requirements for other comprehensive income in the Notice on Printing and Distributing Accounting Standards for Business Enterprises No. 3 2009 No. 8 which further reduced the information asymmetry between investors and listed companies Improve the quality of accounting information. So can China reduce the level of earnings management by increasing the transparency of other comprehensive income disclosures and effectively curb the flooding of earnings management of listed companies?

We believe that by improving the quality of information on listed companies to curb earnings management behavior of listed companies that is through the presentation of other comprehensive income to reduce the transparency of its earnings management. Therefore the following assumptions are presented in this paper.

Hypothesis 1: In the control of other factors, the listed companies' earnings management behavior can be inhibited under the conditions of improving other comprehensive income reporting transparency.

Unlike traditional accrual earnings management through accounting policy choices and accounting estimates companies are increasingly using real business activities for earnings manipulation as this approach is more difficult to identify. The fact that the other comprehensive 
income is reclassified into the profit and loss is the unrecognized gain or loss that has actually been realized. Therefore it is difficult to identify the earnings management method of the time when the other comprehensive gains or losses are realized through the real transaction. This behavior adds to the justification of the argument 4 . Based on this the following assumptions are presented in this paper.

Hypothesis 2: In the control of other factors, the more of the existence of earnings management motivation of listed companies the more other comprehensive income into the proportion of current income.

\subsection{Variable definition}

Table 1 Variables and definitions

\begin{tabular}{|c|c|}
\hline Variables & Variable definitions \\
\hline DA & $\begin{array}{l}\text { operability accrued profits using the modified Jones model to calculate the operability } \\
\text { of accrued profits }\end{array}$ \\
\hline$|\mathrm{DA}|$ & Take the absolute value of the operability accrual in the model \\
\hline $\mathrm{NI}$ & current net profit \\
\hline CFO & Net cash flow from operating activities \\
\hline $\mathrm{G} A_{i, t}$ & company $\mathrm{i}$ Total accrued profit in year t. $\mathrm{GA}_{\mathrm{i}, \mathrm{t}}=\mathrm{NI}_{\mathrm{i}, \mathrm{t}}-\mathrm{CFO}_{\mathrm{i}, \mathrm{t}}$ \\
\hline$A_{i, t-1}$ & The total assets of the company at the end of the year \\
\hline$\Delta \mathrm{REV}_{i, t}$ & The main income changes of the company at the end of the year \\
\hline$\Delta \mathrm{REC}_{i, t}$ & The amount of change in accounts receivable at the end of the year \\
\hline $\mathrm{PPE}_{i, t}$ & $\begin{array}{l}\text { The original value of fixed assets such as plant and equipment of the company at the } \\
\text { end of the year }\end{array}$ \\
\hline CI & Comprehensive income \\
\hline LNSIZE & Company scale (take the natural logarithm of total assets at the end of the year) \\
\hline CrrntR & flow ratio \\
\hline DebtR & Asset - liability ratio \\
\hline OCI & $\begin{array}{l}\text { Other comprehensive income. The amount of other comprehensive income presented } \\
\text { in the income statement. }\end{array}$ \\
\hline STH & $\begin{array}{l}\text { Earnings management motivation. With the core operating profit to express the } \\
\text { degree of business management motivation. STH = Operating profit - Investment } \\
\text { income - Gains and losses from changes in fair value }\end{array}$ \\
\hline OTA & $\begin{array}{l}\text { Financial assets / total assets (available-for-sale financial assets }+ \text { held-to-maturity } \\
\text { investments }+ \text { transactional financial assets }+ \text { long-term equity investments) } / \text { total } \\
\text { assets }\end{array}$ \\
\hline
\end{tabular}




\subsection{Sample selection and data sources}

This paper first of all 2008 to 2015, Shanghai and Shenzhen all A-share listed companies as a sample study. Because the Ministry of Finance introduced in 2009 the presentation of other comprehensive income statements, this paper, in order to compare the data, and taking into account the 2009 listed companies in the income statement almost no other comprehensive income of the presentation, so the study began In 2008, due to the writing of this is the 2016 listed companies in the relevant financial statements data has not yet been published, so the study year ended in 2015. The selected data is then sorted, including the removal of samples from ST, SST, S * ST, PT companies and missing data. The resulting sample data are detailed in Table 3 and Table 4. The relevant financial data in this article is from the Wind database.

\subsection{Model establishment}

\subsubsection{Measurement model of earnings management}

The measure of earnings management is an important subject of western empirical accounting research. The main method is to use "manipulative accruals" to measure the degree of earnings management. Based on previous research results, the degree of earnings management is calculated using the modified Jones model to determine the maneuverability accrual measure. Specific steps are as follows:

3.4.1.1 Regression analysis of the annual sample data of the annual company, and estimated parameter values $\alpha_{1}, \alpha_{2}, \alpha_{3}$;

$$
\frac{\mathrm{GA}_{\mathrm{i}, \mathrm{t}}}{\mathrm{A}_{\mathrm{i}, \mathrm{t}-1}}=\alpha_{0}+\alpha_{1}\left(\frac{1}{\mathrm{~A}_{\mathrm{i}, \mathrm{t}-1}}\right)+\alpha_{2}\left[\frac{\Delta \mathrm{REV}_{\mathrm{i}, \mathrm{t}}-\Delta \mathrm{REC}_{\mathrm{i}, \mathrm{t}}}{\mathrm{A}_{\mathrm{i}, \mathrm{t}-1}}\right]+\alpha_{3}\left(\mathrm{PPE}_{\mathrm{i}, \mathrm{t}} / \mathrm{A}_{\mathrm{i}, \mathrm{t}-1}\right)+\epsilon
$$

$\epsilon$ is the residual value.

3.4.1.2 If the estimated parameters $\left(\alpha_{1}, \alpha_{2}, \alpha_{3}\right)$ obtained in the model (1) been taken into the model (2), we can calculate the listed companies unregulated accrual profit $N D A_{i, t}$ based on the assets of previous year.

$$
\mathrm{NDA}_{\mathrm{i}, \mathrm{t}}=\alpha_{1}\left(\frac{1}{\mathrm{~A}_{\mathrm{i}, \mathrm{t}-1}}\right)+\alpha_{2}\left[\frac{\Delta \mathrm{REV}_{\mathrm{i}, \mathrm{t}}-\Delta \mathrm{REC}_{\mathrm{i}, \mathrm{t}}}{\mathrm{A}_{\mathrm{i}, \mathrm{t}-1}}\right]+\alpha_{3}\left(\mathrm{PPE}_{\mathrm{i}, \mathrm{t}} / \mathrm{A}_{\mathrm{i}, \mathrm{t}-1}\right)
$$

3.4.1.3the comprehensive model (1) and the model (2) calculation results, generation model (3) derived manipulative accrual profits $D A_{i, t}$.

$$
\mathrm{DA}_{\mathrm{i}, \mathrm{t}}=\frac{\mathrm{GA}_{\mathrm{i}, \mathrm{t}}}{\mathrm{A}_{\mathrm{i}, \mathrm{t}-1}}-\mathrm{NDA}_{\mathrm{i}, \mathrm{t}}
$$

3.4.2 Multiple regression analysis of the relationship between other comprehensive income disclosure and earnings management. 
Disclosure of other comprehensive income in the income statement, according to the previous literature research increased the transparency of the statement, should reduce the enterprise earnings management. The model is:

$$
|\mathrm{DA}|=\beta_{0}+\beta_{1} \operatorname{lnSIZE}+\beta_{2} \mathrm{CrrntR}+\beta_{3} \mathrm{DebtR}+\beta_{4} \mathrm{CFO}+\beta_{5} \mathrm{OCI}
$$

Where $|D A|$ is the absolute value of DA.

\subsubsection{Multiple regression analysis of the existence of earnings management motivations of listed companies other comprehensive income into the current income of the impact}

For listed companies, if the core business profit is insufficient, then the listed companies on the existence of earnings management motivation, earnings management is the most effective way to sell financial assets, there will be a lot of other comprehensive income into the current profits and losses and thus affect the current profits. The model is:

$$
\mathrm{OCI}=\beta_{0}+\beta_{1} S T H+\beta_{2} \text { OT } A+\beta_{3} L N S I Z E+\beta_{4} \text { DebtR }
$$

\section{Empirical Results and Analysis}

\subsection{Descriptive statistics}

The descriptive statistics of the relevant variables are shown in Table 2.

Table 2 describes the statistics

\begin{tabular}{|c|c|c|c|c|c|c|}
\hline variable & $\begin{array}{c}\text { Sample } \\
\text { size }\end{array}$ & Mean & $\begin{array}{c}\text { Minimum } \\
\text { value }\end{array}$ & median & $\begin{array}{c}\text { The } \\
\text { maximum } \\
\text { value }\end{array}$ & $\begin{array}{c}\text { Standard } \\
\text { deviation }\end{array}$ \\
\hline $\mid$ DA $\mid$ & 7036 & 0.0979 & 0.0000 & 0.0462 & 6.8722 & 0.2924 \\
\hline LNSIZE & 7036 & 12.9018 & 8.2157 & 12.6941 & 19.2937 & 1.3909 \\
\hline OCI & 7036 & -1590.8451 & -3627700 & -2.5118 & 606520.5482 & 53566.7593 \\
\hline CrrntR & 7036 & 2.6593 & 0.0385 & 1.5440 & 190.8692 & 5.3280 \\
\hline DebtR & 7036 & 45.7220 & 0.7521 & 45.6178 & 861.1787 & 24.1435 \\
\hline CFO & 7036 & 102369.8714 & -2512055.5 & 10997.1105 & 31879600.0 & 1003504.8977 \\
\hline STH & 7036 & 48647.4746 & -9738000 & 7982.6806 & 18604300.0 & 564430.6884 \\
\hline OTA & 7036 & 0.0693 & -0.0484 & 0.0256 & 0.8910 & 0.1134 \\
\hline
\end{tabular}

Through the analysis of the descriptive statistics in Table 2, we find that the $|\mathrm{DA}|$ mean 0.0979 of 7036 sample data of the listed Shenzhen A-share listed companies is significantly different from zero, indicating that the listed companies do exist earnings management behavior, Of the standard deviation of 0.2924 significantly different from zero, indicating that the listed companies are not the same degree of earnings management. STH standard deviation of 564430.6884, the value is relatively large, indicating that the listed company's core earnings profit difference is relatively large, and the earnings management motivation of listed companies in this year's is very different.

\subsection{Multivariate linear regression analysis}

Using the model established above, we further call the $\mathrm{R}$ software for linear regression analysis. The specific results are shown in Table 3. 
Table 3 Model (4) Summary

\begin{tabular}{|c|c|c|c|c|c|c|}
\hline & & LNSIZE & CrrntR & DebtR & CFO & $\mathrm{OCI}$ \\
\hline \multirow{5}{*}{2008} & coefficient & $-2.168 \mathrm{e}-02$ & $8.760 \mathrm{e}-03$ & $-4.249 \mathrm{e}-04$ & $2.633 e-07$ & $-3.562 \mathrm{e}-07$ \\
\hline & $\mathrm{s}$ - stat & $-1.927()$. & 0.849 & -0.477 & 1.050 & -0.595 \\
\hline & $A d j-R^{2}$ & & & $5.176 \%$ & & \\
\hline & F statistic & & & 2.518 & & \\
\hline & sample & & & 141 & & \\
\hline \multirow{5}{*}{2009} & coefficient & $1.672 \mathrm{e}-01$ & $1.352 \mathrm{e}-02$ & $5.304 \mathrm{e}-03$ & $-4.297 \mathrm{e}-09$ & $-1.675 \mathrm{e}-06$ \\
\hline & $s-$ stat & $8.627(* * *)$ & 1.125 & $4.301(* * *)$ & -0.176 & -1.329 \\
\hline & $A d j-R^{2}$ & & & 0.1459 & & \\
\hline & F statistic & & & 28.49 & & \\
\hline & sample & & & 807 & & \\
\hline \multirow{5}{*}{2010} & coefficient & $-2.776 \mathrm{e}-03$ & $3.178 \mathrm{e}-03$ & $3.273 \mathrm{e}-04$ & $-3.439 e-09$ & $1.927 \mathrm{e}-07$ \\
\hline & $\mathrm{s}-\mathrm{stat}$ & -1.177 & $4.336(* * *)$ & $2.101(*)$ & -1.330 & $1.652()$. \\
\hline & $A d j-R^{2}$ & & & $2.313 \%$ & & \\
\hline & F statistic & & & 5.455 & & \\
\hline & sample & & & 943 & & \\
\hline \multirow{5}{*}{2011} & coefficient & $1.044 \mathrm{e}-02$ & $-2.933 e-04$ & $-1.039 \mathrm{e}-03$ & $-1.508 \mathrm{e}-08$ & $-1.657 e-07$ \\
\hline & $\mathrm{s}-\mathrm{stat}$ & $3.617(* * *)$ & -0.678 & $-5.801(* * *)$ & $-3.828(* * *)$ & -1.059 \\
\hline & $A d j-R^{2}$ & & & $4.02 \%$ & & \\
\hline & F statistic & & & 9.402 & & \\
\hline & sample & & & 1006 & & \\
\hline \multirow{5}{*}{2012} & coefficient & $-8.133 e-03$ & $5.308 \mathrm{e}-04$ & $7.487 \mathrm{e}-04$ & $1.684 \mathrm{e}-10$ & $-1.917 \mathrm{e}-07$ \\
\hline & s - stat & $3.619(* * *)$ & 0.860 & $5.214(* * *)$ & 0.056 & -1.012 \\
\hline & $A d j-R^{2}$ & & & $2.48 \%$ & & \\
\hline & F statistic & & & 6.83 & & \\
\hline & sample & & & 1148 & & \\
\hline \multirow{5}{*}{2013} & coefficient & $-8.704 \mathrm{e}-03$ & $2.600 \mathrm{e}-04$ & $8.439 \mathrm{e}-04$ & $-2.269 \mathrm{e}-09$ & $-5.237 \mathrm{e}-08$ \\
\hline & $\mathrm{s}-\mathrm{stat}$ & $5.253(* * *)$ & 0.711 & $11.899(* * *)$ & -0.749 & -0.669 \\
\hline & $A d j-R^{2}$ & & & $10.88 \%$ & & \\
\hline & F statistic & & & 30.56 & & \\
\hline & sample & & & 1213 & & \\
\hline \multirow{5}{*}{2014} & coefficient & $-2.019 \mathrm{e}-02$ & $1.445 \mathrm{e}-03$ & $1.388 \mathrm{e}-03$ & $9.962 \mathrm{e}-09$ & $1.484 \mathrm{e}-07$ \\
\hline & $\mathrm{s}$ - stat & $4.221(* * *)$ & 1.064 & $4.436(* * *)$ & 1.630 & 1.072 \\
\hline & $A d j-R^{2}$ & & & $1.541 \%$ & & \\
\hline & F statistic & & & 5.187 & & \\
\hline & sample & & & 1340 & & \\
\hline \multirow{5}{*}{2015} & coefficient & $1.035 \mathrm{e}-02$ & $3.976 \mathrm{e}-04$ & $4.850 \mathrm{e}-04$ & $-2.547 \mathrm{e}-08$ & $-1.172 \mathrm{e}-07$ \\
\hline & $\mathrm{s}-\mathrm{stat}$ & $1.942()$. & 0.164 & 1.299 & $-2.853(* *)$ & $-1.811()$. \\
\hline & $A d j-R^{2}$ & & & $0.6849 \%$ & & \\
\hline & F statistic & & & 3.134 & & \\
\hline & sample & & & 2719 & & \\
\hline
\end{tabular}

Note: $* * *$ indicates statistically significant at $0.1 \%$ critical level, $* *$ indicates statistically significant at $1 \%$ level, $*$ indicates statistically significant at 5\% level, indicating statistically significant at $10 \%$ level.

From Table 3, the model summary table we can see from 2008 to 2015 , in addition to 2010, the coefficient of other comprehensive income of $1.927 \mathrm{e}-07$, the remaining seven years are negative, indicating that other comprehensive income of the further presentation can inhibit the listing The company uses other comprehensive earnings for earnings management. From the table we can also find that although the coefficient of other comprehensive returns in the regression results of model (4) is negative, the OCI t test is not significant except for the OCI, $t$ test at $10 \%$ in 2015. 
This should be the result of a model that does not take into account the impact of accounting policy changes from 2009 to 2015. In addition, we look at a model (4) goodness of the test results, the adjusted goodness test results in 2013 was $10.88 \%$, other years are less than $10 \%$, good fit is low, which Because the modified Jones model implies an important hypothesis in the model building process, that is, some accounting elements affect the enterprise's non-manipulative accrual items, and these measurement models assume that these accounting elements are neutral. In fact, these accounting elements are not necessarily neutral, and to a certain extent can be manipulated.

Using the model established above, we further call the $\mathrm{R}$ software for linear regression analysis. The specific results are shown in Table 4.

Table 4 Model (5) Summary

\begin{tabular}{|c|c|c|c|c|c|}
\hline & & STH & OTA & LNSIZE & DebtR \\
\hline \multirow[t]{5}{*}{2009} & coefficient & $-2.585 \mathrm{e}-01$ & $7.864 \mathrm{e}+04$ & $1.002 \mathrm{e}+04$ & $-5.778 \mathrm{e}+00$ \\
\hline & s - stat & $-28.299(* * *)$ & $-28.299(* * *)$ & $8.457(* * *)$ & $13.709(* * *)$ \\
\hline & $A d j-R^{2}$ & \multicolumn{4}{|c|}{$55.42 \%$} \\
\hline & F statistic & \multicolumn{4}{|c|}{309.9} \\
\hline & sample & \multicolumn{4}{|c|}{996} \\
\hline \multirow[t]{5}{*}{2010} & coefficient & $-1.205 \mathrm{e}-02$ & $-9.361 \mathrm{e}+04$ & $-9.425 e+03$ & $-1.819 \mathrm{e}+02$ \\
\hline & s - stat & $-6.376(* * *)$ & $-5.188(* * *)$ & $-5.927(* * *)$ & $-1.704(* * *)$ \\
\hline & $A d j-R^{2}$ & \multicolumn{4}{|c|}{$17.53 \%$} \\
\hline & F statistic & \multicolumn{4}{|c|}{49.09} \\
\hline & sample & \multicolumn{4}{|c|}{907} \\
\hline \multirow[t]{5}{*}{2011} & coefficient & $-5.330 \mathrm{e}-03$ & $-1.583 e+05$ & $-1.107 \mathrm{e}+04$ & $1.408 \mathrm{e}+01$ \\
\hline & s - stat & $-2.598(* *)$ & $-6.894(* * *)$ & $-5.917(* * *)$ & 0.109 \\
\hline & $A d j-R^{2}$ & \multicolumn{4}{|c|}{$11.08 \%$} \\
\hline & F statistic & \multicolumn{4}{|c|}{38.14} \\
\hline & sample & \multicolumn{4}{|c|}{1194} \\
\hline \multirow[t]{5}{*}{2012} & coefficient & $-3.221 \mathrm{e}-01$ & $6.163 \mathrm{e}+04$ & $-1.019 \mathrm{e}+03$ & $1.916 \mathrm{e}+01$ \\
\hline & s - stat & $-49.560(* * *)$ & $3.502(* * *)$ & -0.923 & 0.267 \\
\hline & $A d j-R^{2}$ & \multicolumn{4}{|c|}{$73.06 \%$} \\
\hline & F statistic & \multicolumn{4}{|c|}{666.8} \\
\hline & sample & \multicolumn{4}{|c|}{984} \\
\hline \multirow[t]{5}{*}{2013} & coefficient & $-7.876 \mathrm{e}-02$ & $-1.291 \mathrm{e}+05$ & $-4.378 \mathrm{e}+03$ & $-1.166 \mathrm{e}+02$ \\
\hline & s - stat & $-43.119(* * *)$ & $-5.247(* * *)$ & $-2.225(*)$ & -1.253 \\
\hline & $A d j-R^{2}$ & \multicolumn{4}{|c|}{$67.26 \%$} \\
\hline & F statistic & \multicolumn{4}{|c|}{600.5} \\
\hline & sample & \multicolumn{4}{|c|}{1169} \\
\hline \multirow[t]{5}{*}{2014} & coefficient & $-4.957 \mathrm{e}-01$ & $4.126 \mathrm{e}+04$ & $7.759 \mathrm{e}+03$ & $-2.874 \mathrm{e}+02$ \\
\hline & s - stat & $-45.595(* * *)$ & $1.738()$. & $2.748(* *)$ & $-1.903()$. \\
\hline & $A d j-R^{2}$ & \multicolumn{4}{|c|}{$71.62 \%$} \\
\hline & F statistic & \multicolumn{4}{|c|}{618.6} \\
\hline & sample & \multicolumn{4}{|c|}{981} \\
\hline \multirow[t]{5}{*}{2015} & coefficient & $-6.362 \mathrm{e}-02$ & $3.964 \mathrm{e}+04$ & $-2.464 \mathrm{e}+03$ & $-3.886 \mathrm{e}+01$ \\
\hline & s - stat & $-27.704(* * *)$ & $5.726(* * *)$ & $-2.840(* *)$ & -0.798 \\
\hline & $A d j-R^{2}$ & \multicolumn{4}{|c|}{0.5039} \\
\hline & F statistic & \multicolumn{4}{|c|}{240.5} \\
\hline & sample & \multicolumn{4}{|c|}{945} \\
\hline
\end{tabular}

Note: $* * *$ indicates statistically significant at $0.1 \%$ critical level, $* *$ indicates statistically significant at $1 \%$ level, * indicates statistically significant at 5\% level, indicating statistically significant at $10 \%$ level. 
Table 4 above reports the regression results for model (5). From 2009 to 2015, the coefficients of STH are negative, and 6 years in seven years are significant at $0.1 \%$ level, 2011 is significant at $1 \%$ level, indicating that in the control of other effects Factors, the existence of earnings management motives of listed companies other comprehensive income into the proportion of the higher the current income. Hypothesis 2 is verified. In addition to the other six years of 2009, the results show that the other comprehensive income is transferred to the current profit and loss in inverse proportion to the firm's size. The coefficient of LNSIZE is tested by significance at the significance level of 5\%. This is because the larger the size of the company, the more the tax authorities, investors, regulators, corporate profits, other comprehensive income to achieve the higher the cost of earnings management, income, other comprehensive income into the current profit and loss with the company size Into an anti-correlation. Indicating that the larger the size of listed companies, the lower level of company's earnings management. This is because the larger the size of the listed company, the higher the political cost of the listed companies, the larger the listed companies by the state, regulators, investors and other stakeholders more concerned, once found to be interested in earnings management behavior Especially dealing with the risk of the company's issuance of stock financing, the company's social image will have an impact.

\section{Conclusion and Suggestions}

Since 2009, China's Ministry of Finance released the accounting explanation, the listed company's income statement requires the addition of "other comprehensive income" and "total income" two subjects. This paper analyzes the relationship between earnings management and other comprehensive income by analyzing the other comprehensive income and other related subjects in the annual report of Shanghai and Shenzhen from 2008 to 2015. Based on the modified Jones model, we study the relationship between earnings management and other comprehensive income. If other factors keep controlled, the listed companies with surplus management motives have more other comprehensive income that transferred to the current profit and loss. At the same time, the author also draws that the degree of earnings management is negatively correlated with the size of the company. The less the core earnings profit is, the stronger the earnings management motive of the listed companies, and the more part of the other comprehensive income gains and losses. The policy implications of these conclusions are the policies formulated in China in 2014 for the detailed reporting of other comprehensive benefits. It is advantageous to reduce the degree of earnings management of listed companies. According to the empirical results, the standard-setting body can further report the other comprehensive income in the report to achieve the purification and improve the quality of listed companies report the purpose. Based on this, the author made the following recommendations:

First of all, for the standard-setting body, in order to make the other comprehensive income information more open and transparent, you can further refine the other comprehensive income, including in the income statement, balance sheet and notes. This provides other comprehensive revenue information that can better leverage its governance and pricing functions, especially those related to earnings management. Second, for investors, corporate creditors and other comprehensive income accounting information users, because the listed companies may use other comprehensive income to improve the company's annual operating profit behavior, so the use of listed companies in the statements of the decision-making, we should pay attention to distinguish between other comprehensive Income into the specific source of profit and loss, so as to improve 
the correctness of decision-making. Finally, for the listed companies, the Ministry of Finance since 2009 in the accounting explanation of the announcement to 2014 in the accounting standards for the mandatory presentation of other comprehensive income information transparency is getting higher and higher, listed companies should actively respond to the Ministry of Finance accounting policy. On the one hand to further standardize and improve the company for other related matters related to the decision-making and internal management, standardize the other comprehensive income recognition, measurement and reporting, in the legal compliance within the scope of the company's economic profits. On the other hand, the company to strengthen the company's accounting and financial personnel training to improve the relevant personnel for other comprehensive income awareness, improve the professional staff of professional competence and professional ethics, to ensure the implementation of new standards and the company's financial information credibility Wait.

\section{References}

Ouyang, A. P. \& Zheng, C. (2014) Research on the usefulness of other comprehensive income credit decisions - based on China A-share listed companies data test. Economics and Management Research, 2014 (8).

Wang, X. (2013) Research on the Value Relativity of Comprehensive Income - Empirical Data Based on New Criterion. Accounting Research, 2013 (10).

Mao, Z. H., Wang, P. \& Ji, F. (2009) Disclosure and presentation of other comprehensive income - Based on the analysis of the annual report of listed companies in 2009. Accounting Research, 2011 (7).

Healy P. M. \& Palepu K G. (2001) Information Asymmetry, Corporate Disclosure, and the Capital Markets: A Review of the Empirical Disclosure Literature [J]. Journal of Accounting and Economics, 2001.

Hunton J E, Libby R. \& Mazza C. L. (2006) Financial Reporting Transparency and Earning Management [J]. The Accounting Review, 2006.

Lynn, L. R. \& B. S. Philip. (2012) Academic Research and Standard-Setting: The Case of Other Comprehensive Income. Accounting Horizons, 2012. 